\title{
2005s-21 \\ The Pigouvian Tax Rule in the Presence of an Eco-Industry
}

\author{
Alain-Désiré Nimubona \\ Bernard Sinclair-Desgagné
}

\begin{tabular}{c}
\hline Série Scientifique \\
Scientific Series
\end{tabular}

\begin{abstract}
Montréal
Avril 2005
\end{abstract}

C 2005 Alain-Désiré Nimubona, Bernard Sinclair-Desgagné. Tous droits réservés. All rights reserved.

Reproduction partielle permise avec citation du document source, incluant la notice (C)

Short sections may be quoted without explicit permission, if full credit, including (C) notice, is given to the source.
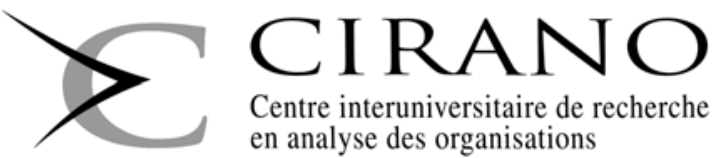

Centre interuniversitaire de recherche en analyse des organisations 


\section{CIRANO}

Le CIRANO est un organisme sans but lucratif constitué en vertu de la Loi des compagnies du Québec. Le financement de son infrastructure et de ses activités de recherche provient des cotisations de ses organisations-membres, d'une subvention d'infrastructure du Ministère du Développement économique et régional et de la Recherche, de même que des subventions et mandats obtenus par ses équipes de recherche.

CIRANO is a private non-profit organization incorporated under the Québec Companies Act. Its infrastructure and research activities are funded through fees paid by member organizations, an infrastructure grant from the Ministère du Développement économique et régional et de la Recherche, and grants and research mandates obtained by its research teams.

PARTENAIRE MAJEUR

\section{Les organisations-partenaires / The Partner Organizations}

. Ministère du Développement économique, de Innovation et de l'Exportation

PARTENAIRES

. Alcan inc.

. Axa Canada

. Banque du Canada

. Banque Laurentienne du Canada

. Banque Nationale du Canada

. Banque Royale du Canada

. Bell Canada

. BMO Groupe financier

. Bombardier

. Bourse de Montréal

. Caisse de dépôt et placement du Québec

. Fédération des caisses Desjardins du Québec

. GazMétro

. Groupe financier Norshield

. Hydro-Québec

. Industrie Canada

. Ministère des Finances du Québec

. Pratt \& Whitney Canada

. Raymond Chabot Grant Thornton

. Ville de Montréal

. École Polytechnique de Montréal

. HEC Montréal

. Université Concordia

. Université de Montréal

. Université du Québec

. Université du Québec à Montréal

. Université Laval

. Université McGill

. Université de Sherbrooke

ASSOCIE A :

. Institut de Finance Mathématique de Montréal (IFM²)

. Laboratoires universitaires Bell Canada

. Réseau de calcul et de modélisation mathématique $\left[\mathrm{RCM}^{2}\right]$

. Réseau de centres d'excellence MITACS (Les mathématiques des technologies de l'information et des systèmes complexes)

Les cahiers de la série scientifique (CS) visent à rendre accessibles des résultats de recherche effectuée au CIRANO afin de susciter échanges et commentaires. Ces cahiers sont écrits dans le style des publications scientifiques. Les idées et les opinions émises sont sous l'unique responsabilité des auteurs et ne représentent pas nécessairement les positions du CIRANO ou de ses partenaires.

This paper presents research carried out at CIRANO and aims at encouraging discussion and comment. The observations and viewpoints expressed are the sole responsibility of the authors. They do not necessarily represent positions of CIRANO or its partners. 


\title{
The Pigouvian Tax Rule in the Presence of an Eco-Industry*
}

\author{
Alain-Désiré Nimubona ${ }^{\dagger}$, Bernard Sinclair-Desgagnét
}

\begin{abstract}
Résumé / Abstract
La production des biens et services destinés à reduire la pollution incombe actuellement souvent à des firmes spécialisées qui forment ce que l'on appelle maintenant l'« écoindustrie ». Cette note reconsidère les taxes pigouviennes dans ce contexte. Il est démontré que la taxe optimale sur les émissions polluantes divergera du coût social marginal de la pollution selon les pouvoirs de marché relatifs des pollueurs et des entreprises environnementales.
\end{abstract}

Mots clés : taxes pigouviennes, industries de l'environnement

Pollution abatement goods and services are now largely being delivered by a specialized "eco-industry." This note reconsiders Pigouvian taxes in this context. We find that the optimal emission tax will depart from the marginal social cost of pollution according to the polluters' and the environment firms' relative market power.

Keywords: Pigouvian taxes, environment industry

Codes JEL : H23, L13

\footnotetext{
${ }^{*}$ We are grateful to Hass an Benchekroun, Robert Cairns, Maia David, Andrew Leach, and seminar audiences at HEC Montréal and McGill University for helpful comments.

${ }^{\dagger}$ Institut d'économie appliquée, HEC Montréal

*École polytechnique, France; CIRANO, CIRAIG et HEC Montréal, Canada. Adresse : 3000 Chemin de la Côte-Sainte-Catherine, Montréal (Québec), Canada H3T 2A7; tel. 1514 340-6461; fax. 1514 340-6469.

Courriel : Bernard.Sinclair-Desgagne@hec.ca
} 


\section{Introduction}

In his classical analysis of market failure, Arthur Pigou (1920) showed that the negative externalities caused by pollution would be internalized by the market if polluters paid a tax equal to the marginal social cost of polluting emissions. This proposition, derived under the assumption of perfect competition, was later amended by Buchanan (1969) and Barnett (1980): when the polluting industry is imperfectly competitive, an emission tax should be set lower than the marginal social cost of pollution, because it trades off the desire to provide incentives for abatement and the necessity to prevent a greater contraction of output. Several authors (see, for example, Katsoulacos and Xepapadeas, 1995; Long and Soubeyran, 1999; Morgenstern, 1995; and Smith, 1992) have now explored, qualified and refined the latter conclusion under more specific industry structures.

All these studies, however, (in fact, all environmental economics so far) postulate that a polluting firm possesses its own internal abatement technology. But nowadays, abatement goods and services are largely procured from specialized environment firms, and this so-called "eco-industry" looks rather concentrated (see Barton, 1997; Davies, 2002; the European Commission, 1999; Karliner, 1999; the OECD, 1996; and the World Trade Organization, 1998). In a recent paper that first acknowledges this situation, David and Sinclair-Desgagné (2005) amended Pigou's basic framework and found that an optimal emission tax should now be set higher than the marginal social cost of pollution. Intuitively, imperfect competition between environment firms results in abatement prices larger than the marginal cost of abatement; emission taxes must then be raised in order 
to make polluters reduce their emissions sufficiently. This note examines whether and to what extent a similar conclusion holds in the Buchanan-Barnett context. The upshot is that the optimal emission tax needs in general to adjust to the polluters' and the abatement suppliers' relative market power. It may happen, for instance, that the distortions respectively present on the product and the abatement markets offset each other to the point that the optimal emission tax turns out to be the one prescribed initially by Pigou.

The paper unfolds as follows. Section 2 presents the model. Section 3 derives and discusses our results. Section 4 contains concluding remarks.

\section{The model}

First consider $n$ identical firms competing à la Cournot. Each firm $i$ produces a quantity $x_{i}$ of a final good at a cost $C\left(x_{i}\right)$, where the latter function is twice differentiable, strictly increasing and convex. Consumers' preferences for this final good are captured by the inverse demand function $p(X), X=\sum_{i=1}^{n} x_{i}, p^{\prime}(X)<0$. Each firm also generates polluting emissions according to an emission function $e\left(x_{i}, a_{i}\right)$, where $a_{i}$ represents firm $i$ 's abatement effort. We assume that $e\left(x_{i}, a_{i}\right)=w\left(x_{i}\right)-a_{i}, w^{\prime}\left(x_{i}\right)>0$ and $w^{\prime \prime}\left(x_{i}\right) \geq 0 .{ }^{1}$

Now, let the abatement goods and services be supplied by a Cournot oligopoly comprising $m$ similar environment firms. Firm $j$ 's cost of delivering an amount $a_{j}$ of such

\footnotetext{
${ }^{1}$ Our qualitative results remain valid without assuming an additively separable emission function. This assumption greatly simplifies the upcoming computations, however. It has been used in several previous works (Barnett, 1980; Katsoulacos and Xepapadeas, 1995; Farzin and Kort, 2001; David and SinclairDesgagné, 2005). It also fits end-of-pipe abatement activities, such as solid waste management, waste water treatment, air pollution control, contaminated soil and groundwater remediation, which currently draw (by far) the largest share of abatement expenses (European Commission, 1999).
} 
goods and services is given by $G\left(a_{j}\right)$, with $G^{\prime}$ and $G^{\prime \prime}$ strictly positive. When the market for abatement is characterized by the inverse demand function $q(A), A=\sum_{j=1}^{m} a_{j}$, $q^{\prime}(A)<0$, each environment firm offers a quantity $a_{j}$ that maximizes the profit function

$$
\Pi_{j}\left(a_{j}\right)=q(A) a_{j}-G\left(a_{j}\right) .
$$

Satisfying simultaneously the (necessary and sufficient) first-order conditions

$$
q(A)=G^{\prime}\left(a_{j}\right)-q^{\prime}(A) a_{j}, \quad j=1, \ldots, m
$$

then yields a Cournot-Nash equilibrium for the eco-industry.

From now on, we shall focus on symmetric equilibria, so a representative polluter $i$ 's production and abatement are respectively given by $x=\frac{X}{n}$ and $a_{i}=\frac{A}{n}$, and a representative environment firm $j$ 's delivered quantity of abatement is $a_{j}=\frac{A}{m}$.

\section{Optimal emission taxes}

Suppose that each unit of pollution bears a positive social cost $\nu$. A benevolent and informed regulator may now want to impose a tax $t$ on polluting emissions. Ignoring redistribution and income transfer issues, this tax would maximize the social welfare objective

$$
W(t)=\int_{0}^{X^{t}} p(z) d z-n C\left(x^{t}\right)-m G\left(a_{j}^{t}\right)-n v e\left(x^{t}, a_{i}^{t}\right),
$$


where by symmetry $x^{t}=\frac{X^{t}}{n}, a_{i}^{t}=\frac{A^{t}}{n}$, and $a_{j}^{t}=\frac{A^{t}}{m}$. After we drop the superscript ${ }^{t}$ (remembering throughout that abatement and output levels depend on the tax $t$ ), the necessary and sufficient first-order condition for an optimal emission tax is given by

$$
W^{\prime}(t)=n\left[p(X)-C^{\prime}(x)\right] \frac{d x}{d t}-n G^{\prime}\left(\frac{n a_{i}}{m}\right) \frac{d a_{i}}{d t}-n v\left[w^{\prime}(x) \frac{d x}{d t}-\frac{d a_{i}}{d t}\right]=0 .
$$

A representative polluter will react to this tax by maximizing the profit function

$$
\Pi_{i}\left(x, a_{i}\right)=p(X) x-C(x)-q(A) a_{i}-t e\left(x, a_{i}\right) .
$$

This is achieved if the following first-order (necessary and sufficient) conditions hold:

$$
\begin{aligned}
p(X)-C^{\prime}(x) & =-p^{\prime}(X) x+t w^{\prime}(x), \\
q(A) & =-q^{\prime}(A) a_{i}+t .
\end{aligned}
$$

Standard comparative statics on equations (3) and (4) confirms that $\frac{d x}{d t}$ and $\frac{d a_{i}}{d t}$ are respectively negative and positive, meaning that a larger tax on polluting emissions generates less production of the final good and greater abatement efforts.

Substituting (1), (3) and (4) into expression (2) now yields the general formula for the Pigouvian tax rule:

$$
t=v+\frac{\frac{X}{n} p^{\prime}(X) \frac{d x}{d t}+\left(\frac{A}{m}-\frac{A}{n}\right) q^{\prime}(A) \frac{d a_{i}}{d t}}{w^{\prime}(x) \frac{d x}{d t}-\frac{d a_{i}}{d t}}
$$

Note that the denominator on the right-hand side is negative. 
Were the eco-industry perfectly competitive, which amounts here to letting $m \rightarrow \infty$, the regulator should set $t=v$ if $n$ also tends to infinity (as Pigou (1920) first proposed) or $t<v$ if $n$ is finite (in agreement with Buchanan (1969) and Barnett (1980), but with an additional downward adjustment due to the term $-\frac{A}{n} q^{\prime}(A) \frac{d a_{i}}{d t}$ which expresses the polluting firms' oligopsony in the abatement market).

Let now $m<\infty$, so the eco-industry is imperfectly competitive. By (1), the price of abatement in this case is equal to the marginal cost $G^{\prime}\left(\frac{A}{m}\right)$ plus a markup $\frac{A}{m} q^{\prime}(A)$. This markup further dissuades polluters from investing in abatement. To counter this, the regulator has to play tougher on polluting emissions. ${ }^{2}$ Indeed, when $n$ is infinite (so polluters are price-takers), formula (5) coincides with the one obtained by David and Sinclair-Desgagné (2005) and we have that $t>v$. With $n$ also finite, however, the regulator must deal with the exercise of market power by polluting firms in the final good market, which lowers consumer surplus, together with the simultaneous presence of an oligopsony and an oligopoly in the abatement market, which both hinder pollution reduction. After some algebra, the numerator on the right-hand-side of (5) indicates that

$$
\begin{array}{cll}
> & \\
t & v \text { if and only if }\left(\frac{n-m}{n}\right)\left(q(A) \frac{d a_{i}}{d t}\right) L_{E C O} & =\left(-p(X) \frac{d x}{d t}\right) L_{P R O D} \\
< & <
\end{array}
$$

\footnotetext{
${ }^{2}$ In practice, environmental policy has to also cope with the possibility of exit from the polluting sector and entry in the eco-industry, and take into account the redistribution of revenues from polluting to environment firms. A careful treatment of these issues is obviously beyond the scope of this note.
} 
where $L_{E C O}$ and $L_{P R O D}$ are the Lerner indices associated with the eco-industry and the final good market respectively. ${ }^{3}$ As the environment firms' market power matters relatively more (less), so $\frac{n-m}{n}$ or $\frac{L_{E C O}}{L_{P R O D}}$ increases (decreases), the regulator would now impose a higher (lower) tax on emissions. This tax will approximate Pigou (1920)'s recommendation when the upstream and downstream industry structures are such that

$$
\frac{L_{P R O D}}{L_{E C O}} \approx \frac{m-n}{n} \frac{q(A)}{p(X)} \frac{\frac{d a_{i}}{d t}}{\frac{d x}{d t}}
$$

\section{Concluding remarks}

This paper showed that taxes targetting polluting emissions must adjust to the relative market power of environment firms (on the abatement market) and polluters (on both the final good and the abatement markets). All things equal, a relatively more concentrated and powerful eco-industry warrants higher emission taxes.

The impact of more complex and realistic industry structures - with endogenous entry and exit, or privately informed and heterogeneous environment firms, for example - on Pigouvian taxes and environmental regulation in general remains to be explored. Pursuing this path, henceforth investigating the vertical relationships and actual division of labor between polluting firms and their abatement suppliers, will certainly shed light on the

\footnotetext{
${ }^{3}$ Defined as the difference between the firm's price and its marginal cost, divided by the firm's price, the Lerner index is a well-known measure of a firm's market power. Here we have that $L_{E C O}=\frac{q(A)-G\left(a_{j}\right)}{q(A)}=$ $\frac{1}{m|\eta|}$ and $L_{P R O D}=\frac{p(X)-C^{\prime}(x)}{p(X)}=\frac{1}{n|\varepsilon|}$, where $\varepsilon$ and $\eta$ are the price-elasticities of demand for the final good and for the abatement goods and services respectively.
} 
current black box of abatement costs, for the greater effectiveness of environmental policy.

\section{References}

Barnett, A. H., 1980. The Pigouvian tax rule under monopoly. American Economic Review 70, 1037-1041.

Barton, J. R., 1997. The North-South dimension of the environment and cleaner technology industries. Discussion Paper no. 9803, Institute for New Technologies, United Nations University, Maastricht, The Netherlands.

Buchanan, J. M., 1969. External diseconomies, corrective taxes, and market structure. American Economic Review 59, 174-177.

David, M., Sinclair-Desgagné, B., 2005. Environmental regulation and the eco-industry. To appear in the Journal of Regulatory Economics.

Davies, S., 2002. Waste management multinationals 2002. Mimeo, Public Services International research Unit (PSIRU), School of Computing and Mathematical Sciences, University of Greenwich.

European Commission, 1999. The EU Ecoindustry's Export Potential: Final Report to DGXI of the European Commission. Brussels.

Farzin, H., Kort, P., 2001. Pollution abatement investments when environmental regulation is uncertain. Journal of Public Economic Theory 2, 183-212.

Katsoulacos, Y., Xepapadeas, A., 1995. Environmental policy under oligopoly with endogenous market structure. Scandinavian Journal of Economics 97, 411-420.

Karliner, J., 1994. The environment industry: Profiting from pollution. The Ecologist 24, $59-63$.

Long, N. V., Soubeyran, A., 1999. Pollution, Pigouvian taxes, and asymmetric international oligopoly. CIRANO Working Paper, Montréal.

Morgenstern, R., 1995. Environmental taxes: dead or alive? Ressources for the Future, Working Paper 96-03.

Organization for Economic Cooperation and Development, 1996. The Global Environmental Goods and Services Industry (OECD Editions, Paris).

Pigou, A. C., 1920. The Economics of Welfare (Macmillan, London).

Smith S., 1992. Taxation and the environment: a survey. Mimeo, Centre for Social and Economic Research on the Global Environment (CSERGE), University of East Anglia.

World Trade Organization, 1998. Environmental services. Chapter IX of the Committee on Trade and Environment's note on Environmental Benefits of Removing Trade Restrictions and Distortions. 